\title{
Traumatic Injuries of the Cervical Cord and Spine
}

\author{
MINORU SHIGEMORI, TATSUO YUGE, TAKASHI TOKUTOMI, \\ TAKEYUKI OGATA, KIYOYOSHI KOBAYASHI \\ AND SHINKEN KURAMOTO
}
Department of Neurosurgery, Kurume University School of Medicine, Kurume, 830 Japan

Received for publication March 25, 1983

\begin{abstract}
Summary: Eighteen patients with traumatic injuries of the cervical spine and cord have been treated in our department during the last 15 years. A review of these patients and results of treatment were described. Factors affecting the outcome of traumatic cervical injuries were also analyzed.
\end{abstract}

Key words: cervical injury - cervical spine - cervical cord -- spinal cord injury - Odontoid fracture - atlanto-axial dislocation - myelography

\section{Introduction}

Traumatic injuries of the cervical cord and spine are frequently encountered at neurosurgical clinic as an associated lesion with head trauma. 18 patients with traumatic cervical injury have been treated in our clinic during the last 15 years. A review of these patients was undertaken to indentify the factors affecting the outcome of traumatic cervical injury and the results of treatment.

\section{Clinical Cases and Method}

The study included 18 patients with traumatic injury of the cervical cord and spine who were admitted and treated by our department since 1968. All but one patient was male and the age ranged from 6 months to 83 years with an average 40 years. The time between injury and admission varied from one hour to 3 months. In all patients with acute cervical cord injury, the airways, and blood pressure were immediately stabilized and the patients were immobilized in skeletal or Glisson traction units. A steroid and mannitol at standard dose were administered to most patients. Following an $\mathrm{x}$-ray examination of the cervical spine, a myelogram was performed when subarachnoid block was suspected from the Queckenstedt test. Surgical treatment was performed in 2 patients with complete subarachnoid block. Conservative treatment consisted of plaster casting or spinal orthosis following traction. Surgical treatment was also performed in patients with unstable odontoid fractures. In this series, the clinical findings, the mechanism of injury, the radiological findings and the managements were analyzed (Table 1). The mechanism of injury was judged by mode of injury, site of soft-tissue lesion and $\mathrm{x}$-ray finding, and divided into hyperextension and hyperflexion injuries. The level of cervical cord injuries were divided into upper $\left(\mathrm{C}_{1}-\mathrm{C}_{2}\right)$ and lower $\left(\mathrm{C}_{3}\right.$ $\mathrm{C}_{8}$ ) cervical lesion. The type of cord lesion was classified as complete cord, incomplete cord, central cord and Brown-Séquard type according to the neurological status. The outcomes of the patients were classified 
TABLE 1

Cases with traumatic injury of the cervical spine and cord (1968-1982)

\begin{tabular}{|c|c|c|c|c|c|c|c|c|c|}
\hline \multirow{2}{*}{ No. } & \multirow{2}{*}{ Year } & \multirow{2}{*}{ Name } & \multirow{2}{*}{ Age(yrs) } & \multirow{2}{*}{ Sex } & \multirow{2}{*}{ Cause of Injury } & \multirow{2}{*}{$\begin{array}{l}\text { Possible Mechanism } \\
\text { of Injury }\end{array}$} & \multicolumn{2}{|c|}{ Lesions } & \multirow{2}{*}{ Associated Injuries } \\
\hline & & & & & & & Spine & Cord & \\
\hline 1. & 1968 & T. S. & 27 & M. & $\begin{array}{l}\text { collision (motor } \\
\text { vehicle accident) }\end{array}$ & unknown & - & + & head trauma (I) \\
\hline 2. & 1973 & F.N. & 18 & M. & rugby foot ball & hyperflexion (?) & + & - & head trauma (I) \\
\hline 3. & 1973 & W. I. & 15 & M. & diving & hyperflexion & + & + & head trauma (I) \\
\hline 4. & 1973 & T.S. & 44 & M. & bicycle accident & hyperextension & - & + & $\begin{array}{l}\text { head trauma (III) } \\
\text { facial trauma }\end{array}$ \\
\hline 5. & 1974 & D. F. & 83 & M. & fall from height & hyperextension & + & + & head trauma (III) \\
\hline 6. & 1974 & K. K. & 60 & M. & stone fell on head & hyperflexion & + & + & head trauma (II) \\
\hline 7. & 1975 & N. T. & 58 & M. & fall from height & hyperflexion & - & + & head trauma (I) \\
\hline 8. & 1976 & $\mathrm{~K} . \mathrm{K}$. & 59 & M. & fall from height & hyperextension & - & + & head trauma (II) \\
\hline 9. & 1978 & $\mathrm{~K} . \mathrm{T}$. & 47 & M. & hit by car & hyperflexion & + & + & head trauma (III) \\
\hline 10. & 1979 & T.N. & 0.6 & M. & fall at home & flexion (lateral ?) & $+(?)$ & - & head trauma (I) \\
\hline 11. & 1980 & $\mathrm{~K} . \mathrm{H}$. & 16 & M. & hit by car & unknown & - & + & head trauma (II) \\
\hline 12. & 1980 & S.Y. & 39 & M. & $\begin{array}{l}\text { fall from moving } \\
\text { vehicle }\end{array}$ & hyperextension & + & - & head trauma (II) \\
\hline 13. & 1982 & S.H. & 59 & M. & fall from height & hyperextension & + & + & head trauma (?) \\
\hline 14. & 1982 & $\mathrm{~T} . \mathrm{S}$. & 62 & M. & automobile accident & t hyperflexion & + & + & $\begin{array}{l}\text { head trauma (II) } \\
\text { facial trauma }\end{array}$ \\
\hline 15. & 1982 & Y. K. & 11 & M. & hit by car & hyperflexion & + & - & $\begin{array}{l}\text { head trauma (III) } \\
\text { hemo-pneumothorax }\end{array}$ \\
\hline 16. & 1982 & $\mathrm{~T} . \mathrm{T}$. & 26 & M. & diving & hyperflexion & + & + & head trauma (I) \\
\hline 17. & 1982 & Y.T. & 56 & M. & fall at home & hyperextension & - & + & $\begin{array}{l}\text { head trauma (I ) } \\
\text { facial trauma }\end{array}$ \\
\hline 18. & 1982 & N.M. & 58 & $\mathrm{~F}$. & fall from hight & hyperflexion & + & + & head trauma (I) \\
\hline
\end{tabular}


TABLE 2

Traumatic cervical cord injuries (14 cases)

\begin{tabular}{|c|c|c|c|c|c|c|c|c|}
\hline No. & Name & $\operatorname{Age}(y r s)$ & Sex & $\begin{array}{l}\text { Time from In jury } \\
\text { to Admission }\end{array}$ & $\mathrm{X}-\mathrm{P}$ Findings & $\begin{array}{l}\text { Level and Type } \\
\text { of Lesions }\end{array}$ & Managements & Outcome \\
\hline 1. & T.S. & 27 & M. & 3 months & normal & $\mathrm{C}_{4}$ Brown-Séquard & conservative & fair \\
\hline 2. & W. I . & 15 & M. & 3 hours & $\begin{array}{l}\text { fracture dislocation } \\
\left(\mathrm{C}_{4}-\mathrm{C}_{5}\right)\end{array}$ & $\mathrm{C}_{5}$ complete cord & conservative & dead \\
\hline 3. & T. S. & 44 & M. & 5 months & normal & $\mathrm{C}_{5}$ incomplete cord & conservative & fair \\
\hline 4. & D. F. & 83 & M. & 24 hours & chip fracture $\left(\mathrm{C}_{3}\right)$ & $\mathrm{C}_{6}$ complete cord & conservative & dead \\
\hline 5. & K. K. & 60 & M. & 11 hours & $\begin{array}{l}\text { fracture of spinous } \\
\text { process }\left(C_{4} \text { and } C_{5}\right)\end{array}$ & $\mathrm{C}_{4}$ complete cord & conservative & poor \\
\hline 6. & N.T. & 58 & M. & 3 hours & normal & $\mathrm{C}_{5}$ central cord & conservative & good \\
\hline 7. & K. K. & 59 & M. & 5 days & $\begin{array}{l}\text { congenital narrow } \\
\text { spinal canal }\end{array}$ & $\mathrm{C}_{5}$ complete cord & conservative & poor \\
\hline 8. & $\mathrm{~K} . \mathrm{T}$. & 47 & M. & 10 days & $\begin{array}{l}\text { odontoid fracture } \\
\mathrm{AAD}\end{array}$ & $\mathrm{C}_{5}$ central cord & conservative & fair \\
\hline 9. & K. H. & 16 & M. & 3 days & normal & $\mathrm{C}_{7}$ incomplete cord & conservative & fair \\
\hline 10. & S.H. & 59 & M. & 1 hour & $\begin{array}{l}\text { odontoid fracture } \\
\text { AAD }\end{array}$ & $\mathrm{C}_{2}$ complete cord & conservative & dead \\
\hline 11. & T. S. & 62 & M. & 3 hours & chip fracture $\left(\mathrm{C}_{6}\right)$ & $\mathrm{C}_{5}$ central cord & conservative & fair \\
\hline 12. & T. T. & 26 & M. & 2 hours & $\begin{array}{l}\text { compression fracture } \\
\left(\mathrm{C}_{5}\right)\end{array}$ & $\mathrm{C}_{5}$ complete cord & $\begin{array}{l}\text { surgical (laminectomy } \\
\text { and anterior fusion) }\end{array}$ & poor \\
\hline 13. & Y.T. & 56 & M. & 12 hours & $\begin{array}{l}\text { widened disc space } \\
\left(\mathrm{C}_{5}-\mathrm{C}_{6}\right)\end{array}$ & $\mathrm{C}_{6}$ central cord & conservative & good \\
\hline 14. & N.M. & 58 & $\mathrm{~F}$. & 3 hours & $\begin{array}{l}\text { fracture dislocation } \\
\left(C_{6}-C_{7}\right) \\
\text { chip fracture }\left(C_{7}\right)\end{array}$ & $\mathrm{C}_{6}$ incomplete cord & $\begin{array}{l}\text { surgical } \\
\text { (laminectomy) }\end{array}$ & fair \\
\hline
\end{tabular}


TABLE 3

Cases with upper cervical injuries

\begin{tabular}{|c|c|c|c|c|c|c|c|c|}
\hline No. & Name & Age(yrs) & Sex & $\begin{array}{l}\text { Possible Mechanism } \\
\text { of Injury }\end{array}$ & $\mathrm{X}-\mathrm{P}$ Findings & $\begin{array}{c}\text { Neurological } \\
\text { Manifestations }\end{array}$ & Managements & Outcome \\
\hline 1. & F.N. & 18 & M. & hyperextension (?) & fracture of lamina $\left(\mathrm{C}_{2}\right)$ & radiculopathy & conservative & good \\
\hline 2. & T.N. & 0.6 & M. & flexion (lateral ?) & subluxation? $\left(\mathrm{C}_{2}-\mathrm{C}_{3}\right)$ & radiculopathy (?) & conservative & good \\
\hline 3 . & K. T. & 47 & M. & hyperflexion & $\begin{array}{l}\text { odontoid fracture } \\
\text { AAD (anterior) }\end{array}$ & central cord $\left(\mathrm{C}_{5}\right)$ & conservative & fair \\
\hline 4. & S.Y. & 39 & M. & hyperextension & odontoid fracture & $\begin{array}{l}\text { neck pain and } \\
\text { limited neck motion }\end{array}$ & conservative & good \\
\hline 5 . & S.H. & 59 & M. & hyperextention & $\begin{array}{l}\text { odontoid fracture } \\
\text { AAD (posterior) }\end{array}$ & complete cord $\left(\mathrm{C}_{2}\right)$ & conservative & dead \\
\hline 6. & $\mathrm{Y} . \mathrm{K}$. & 11 & M. & hyperflexion & $\begin{array}{l}\text { odontoid fracture } \\
\text { AAD (anterior) }\end{array}$ & limited neck motion & $\begin{array}{l}\text { surgical (posterior } \\
\mathrm{C}_{1}-\mathrm{C}_{2} \text { fusion) }\end{array}$ & fair \\
\hline
\end{tabular}

AAD: atlanto-axial dislocation
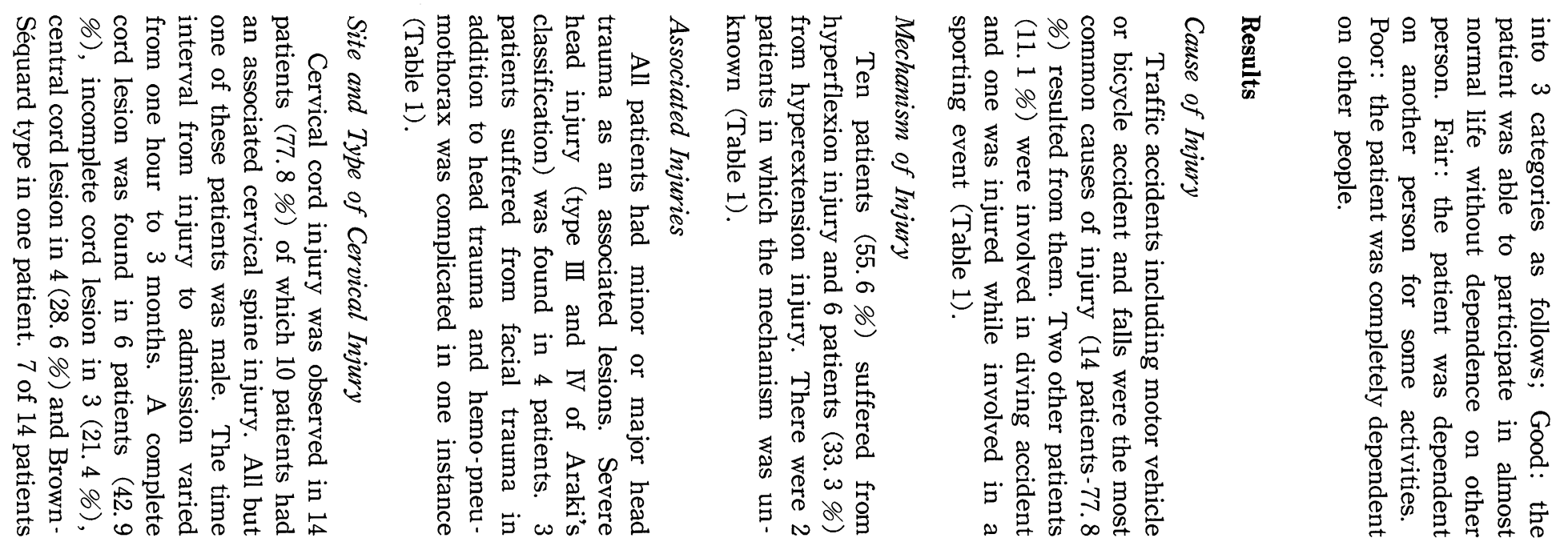
(50\%) had damage at the level of $\mathrm{C}_{5}$ and $3(21.4 \%)$ had damage at $\mathrm{C}_{6}$. Damage in the others was located at $\mathrm{C}_{2}, \mathrm{C}_{4}$ or $\mathrm{C}_{7}$ (Table 2). Upper cervical injuries with or without cord lesions occurred in 6 of 18 patients $(33.3 \%)$ and odontoid fracture was found in 4 patients. Atlanto-axial dislocation was observed in 3 of 4 patients with odontoid fracture. Cervical cord lesion were found in two patients (Table 3 ).

\section{Treatment and Outcome}

Surgical treatment was performed on 2 patients with cord lesions (case 12 and 14 in Table 2). The others were treated conservatively. The former included decompressive laminectomy with or without fusion. The final outcome of the patients with cord lesions was: 2 good (14.3\%), 6 fair $(42.9 \%), 3$ poor $(21.4 \%)$ and the mortality rate was $21.4 \%$ (Table 2 ). All but one patient with upper cervical injuries were treated conservatively and 5 of 6 patients had an outcome of good or fair. Posterior $\mathrm{C}_{1}-\mathrm{C}_{2}$ fusion was done in a surgically treated patient (Table 3 ).

\section{Mechanism of Injury and Cord lesion}

Ten of 12 patients $(83.3 \%$ ) had damage at the $\mathrm{C}_{5}-\mathrm{C}_{6}$ level, of which 6 patients suffered from hyperflexion injury and the other 4 patients suffered from hyperextension injury. 3 of 4 patients with central cord lesions was caused by hyperflexion injury in the present series (Table 4). However there was no correlation between the mechanism of injury and the outcome.

\section{$X-P$ Finding, Cord Lesion and Outcome}

Abnormal findings on plain $\mathrm{X}$-ray film were demonstrated in 12 of 18 patients $(66.7 \%)$ and 10 patients $(55.6 \%)$ had associated cervical cord lesions. The most common features on $\mathrm{x}$-ray film were fracture dislocation ( 2 cases), compression or chip fracture ( 3 cases) and odontoid fracture (4 cases). The latter was found in 2 instances among the patients with cervical cord lesions. No radiological abnormalities were found in 4 of 14 patients $(28.6 \%)$ ). All 6 patients with complete cord lesion had abnormal findings on $\mathrm{x}$-ray film of the spine. The outcome depend upon the pres-

TABLE 4

Mechanism of injury and cord lesion

\begin{tabular}{llll}
\hline $\begin{array}{l}\text { Level of } \\
\text { Cord Lesion }\end{array}$ & Hyperflexion & Hyperextension & Case No. (\%) \\
\hline $\mathrm{C}_{2}$ & 0 & 1 & $1(8.3)$ \\
$\mathrm{C}_{4}$ & 1 & 0 & $1(8.3)$ \\
$\mathrm{C}_{5}$ & 5 & 2 & $7(58.3)$ \\
$\mathrm{C}_{6}$ & 1 & 2 & $3(25.1)$ \\
\hline & $7(58.3)$ & $5(41.7)$ & 12 \\
\hline & & & \\
\hline Type of & & & \\
\hline Cord Lesion & & 3 & $6(50)$ \\
Incomplete Cord & 1 & 1 & $4(33.3)$ \\
Central Cord & 3 & 1 & 12 \\
\hline
\end{tabular}


TABLE 5

$X-P$ Finding and cord lesion

\begin{tabular}{lccccc}
\hline \multicolumn{1}{c}{ X-P Findings } & $\begin{array}{c}\text { Complete } \\
\text { Cord }\end{array}$ & $\begin{array}{c}\text { Incomplete } \\
\text { Cord }\end{array}$ & $\begin{array}{c}\text { Central } \\
\text { Cord }\end{array}$ & Brown-Séquard & Case No. (\%) \\
\hline Fracture Dislocation & 1 & 1 & 0 & 0 & $1(14.3)$ \\
Compression and/ & 2 & 0 & 1 & 0 & $3(21.4)$ \\
or Chip Fracture & 1 & 0 & 1 & 0 & $2(14.3)$ \\
Odontoid Fracture & 1 & 0 & 0 & 0 & $1(7.1)$ \\
Spinous Fracture & 0 & 0 & 1 & 0 & $1(7.1)$ \\
Widened Disc Space & 1 & 0 & 0 & 0 & $1(7.1)$ \\
Congenital Narrow & 0 & 2 & 1 & 1 & $4(28.7)$ \\
Spinal Canal & $6(42.9)$ & $3(21.4)$ & $4(28.7)$ & $1(7.1)$ & 14 \\
\hline Normal & & & & & \\
\hline
\end{tabular}

$X-P$ Finding and outcome

\begin{tabular}{lccccc}
\hline \multicolumn{1}{c}{ X-P Findings } & Good & Fair & Poor & Dead & Case No. (\%) \\
\hline Fracture Dislocation & 0 & 1 & 0 & 1 & $2(14.3)$ \\
Compression and/ & 0 & 1 & 1 & 1 & $3(21.4)$ \\
or Chip Fracture & 0 & 1 & 0 & 1 & $2(14.3)$ \\
Odontoid Fracture & 0 & 0 & 1 & 0 & $1(7.1)$ \\
Spinous Fracture & 1 & 0 & 0 & 0 & $1(7.1)$ \\
Widened Dise Space & 1 & 0 & 1 & 0 & $1(7.1)$ \\
Congenital Narrow & 0 & 3 & 0 & 0 & $4(28.7)$ \\
Spinal Canal & 1 & $6(42.9)$ & $3(21.4)$ & $3(21.4)$ & 14 \\
\hline Normal & $2(14.3)$ & & & & \\
\hline
\end{tabular}

ence of abnormal findings on the $\mathrm{x}$-ray film. All expired patients had severe injury of the cervical spine (Table 5).

\section{Level, Type of Cord Lesion and Outcome}

The cervical cord lesion were located at the lower cervical level in all but one patient in this series $(92.9 \%)$. All patients with complete cord lesions had poor outcomes. Upper cervical cord lesions were also associated with unfavorable outcomes. However central cord lesions and BrownSéquard type had good or fair outcomes. Fifty percent of the patients with central cord lesions became almost normal. The outcome was definitely related to the level and the type of cervical cord lesion (Table 6).

\section{Factors affecting the Outcome of Cervical Cord Injury}

The age of the patients and the time interval from injury to amission had minimal influence on the final outcome. Neither conservative treatment nor surgical treatment in 3 patients affected the outcome. The most important factors for determining the final outcome were the level and type of cervical cord lesion. The mechanism of in jury was also an important prognosticating factor because the type of cord lesion was determined to some degree by the mechanism of the injury. 
TABLE 6

Level of cord lesion and outcome

\begin{tabular}{cccccc}
\hline \multirow{2}{*}{$\begin{array}{l}\text { Level of } \\
\text { Cord Lesion }\end{array}$} & \multicolumn{5}{c}{ Outcome } \\
\cline { 2 - 5 } & Good & Fair & Poor & Dead & \\
\hline $\mathrm{C}_{2}$ & 0 & 0 & 0 & 1 & $1(7.1)$ \\
$\mathrm{C}_{4}$ & 0 & 1 & 1 & 0 & $2(14.3)$ \\
$\mathrm{C}_{5}$ & 1 & 3 & 2 & 1 & $7(50)$ \\
$\mathrm{C}_{6}$ & 1 & 1 & 0 & 1 & $3(21.4)$ \\
$\mathrm{C}_{7}$ & 0 & 1 & 0 & 0 & $1(7.1)$ \\
\hline & 2 & 6 & 3 & 3 & 14 \\
\hline
\end{tabular}

Type of cord lesion and outcome

\begin{tabular}{lccccc}
\hline \multirow{2}{*}{$\begin{array}{l}\text { Type of } \\
\text { Cord Lesion }\end{array}$} & \multicolumn{5}{c}{ Outcome } \\
\cline { 2 - 5 } & Good & Fair & Poor & Dead & \\
\hline Complete Cord & 0 & 0 & 3 & 3 & $6(42.9)$ \\
Incomplete Cord & 0 & 3 & 0 & 0 & $3(21.4)$ \\
Central Cord & 2 & 2 & 0 & 0 & $4(28.6)$ \\
Brown-Séquard & 0 & 1 & 0 & 0 & $1(7.1)$ \\
\hline & 2 & 6 & 3 & 3 & 14 \\
& $(14.3)$ & $(42.9)$ & $(21.4)$ & $(21.4)$ & \\
\hline
\end{tabular}

\section{Discussion}

Traumatic injury of the cervical cord and spine are commonly associated with head or facial injuries. Cervical trauma is occasionally undiagnosed when the patients have consciousness or when there are severe neurological deficits after head injury. Therefore, a meticulous neurological examination, $\mathrm{x}$-ray of the cervical spine and intracranial investigations are essential for patients with severe head injuries.

The proposed mechanisms of cervical cord injuries are fracture dislocation for complete cord transection, hyperextension for central cord syndrome, unilateral facet subluxation for Brown-Séquard type and burst fracture or disc retropulsion for anterior cord syndrome (Marar, 1974). Schneider (1954) has previously shown that the mechanism of acute central cord syn- drome is hyperextension. It has also been suggested recently that flexion forces to the spine of children produce more serious neural in juries than extension forces (Pang, 1982). In contrast to their descriptions, we observed no definite correlation between the mechanism of injury and the type of cord lesion except in the patients with central cord lesions where hyperflexion injury was more frequent.

As to the injury site of the cervical cord, cord damage most likely occurred at $\mathrm{C}_{5}-\mathrm{C}_{6}$ because hyperextension is maximum at thier junction (Scher, 1980) and the fulcrum for maximum flexion is also at this level (Braakman, 1968). Our present results also support this concept and 10 of 14 patients with cord lesion had damage at this level irrespective of the injury mechanism.

The age of the patient and the time of 
treatment had no significant effect upon the final outcome. Early surgical therapy, or medical treatments such as steroid or mannitol, also did not influence the outcome. The only important factors were the level and the type of cord lesion, although the mechanism of injury and the presence of abnormal findings on the $x$-ray of the spine had some relationship to the severity of the cord lesion. Similar conclusions were presented recently stating that the initial injury remained the primary determinant of the neurological outcome (Wagner, 1982). Incomplete injuries of the cord had a significant potential for improvement, but complete lesion seldom improved (Chehrazi, 1981), and complete severe lesions did not recover. Only those with initially mild neural injuries make satisfactory neurological recovery even in the pediatric spinal cord injury (Pang, 1982).

Anderson and D'Alonzo (1974) suggested that the decision to perform early fusion rather than immobilization should be based on the location of odontoid fracture although the optimal management of this fracture remains controversial (Maiman, 1982). They have developed an anatomically based classification system: type 1 with fracture of the tip of the odontoid process; type 2 with fracture through the base of the odontoid process at the junction of the body of $\mathrm{C}_{2}$-this is the most common type; type 3 with fracture through the body of $\mathrm{C}_{2}$. Three of four patients with odontoid fracture in our series had Type 2 fractures and surgical treatment was performed in one child. Maiman (1982) recommended traction followed by posterior fusion for Type 2 fractures. This was performed in our patient because the surgical and long term morbidity is low, and satisfactory fusion can be expected.

Immobilization and reduction of fracturedislocation with skeletal traction are well accepted measures in the management of patients with acute cervical cord injuries (Norrell, 1980) and neuronal compression is the primary indication for surgical decompression (Jelsma, 1982). We believe that early decompression for patients with complete cord lesion with subarachnoid block on myelogram is effective in preventing secondary cord injury due to edema or swelling from the result of the surgically treated patient (Case 12 in Table 2). This patient suffered a hyperflexion injury from diving which resulted in a complete cord lesion at the level of $\mathrm{C}_{5}$. Twelve hours after the injury, the patient underwent decompressive laminectomies between $\mathrm{C}_{3}$ $\mathrm{C}_{6}$ and a dural opening which was followed by anterior fusion. There was no aggravation of the neurological deficits or the ascending paralysis after the operation in this patient. In comparison a conservatively treated 15-year-old boy (Case 2 in Table 2) also manifested complete cord signs at the same level with complete subarachnoid block. The latter developed progressive neurological aggravation and died because of ascending paralysis due to secondary injury to the cervical cord. Further experience with early decompressive surgery for complete cord lesions with subarachnoid block may clarify the efficacy of this treatment for severe cervical cord injury with disappointing outcome.

\section{References}

Anderson, L. D. and D'Alonzo, R. T. (1974). Fractures of the odontoid process of the axis. J. Bone Joint Surg. 56, 1663-1674.

BraAkman, R. and Penning, L. (1968). The hyperflexion sprain of the cervical spine. Radiol. Clin. 37, 309-320.

Chelrazi, B., Wagner, F. C., Collins, W. F. and Freeman, D.H. (1981). A scale for evaluation of spinal cord injury. J. Neurosurg. 54, 310315.

Jelsma, R. K., Rice, J. F., Jelsma, L. F. and KIRSCH, P.T. (1982). The demonstration and significance of neural compression after spinal injury. Surg. Neurol. 18, 79-92.

Maiman, D. J. and Larson, S. J. (1982). Manage- 
ment of odontoid fractures. Neurosurgery, 11, 471-476.

MARAR, B.C. (1974). The pattern of neurological damage as an aid to the diagnosis of the mechanism in cervical-spine injuries. J. Bone Joint Surg. 56, 1648-1654.

Norrell, H. (1980). The early management of spinal injuries. Clin. Neurosurg. 27, 385-400.

PANG, D. and Wilderger, J.E. (1982). Spinal cord injury without radiographic abnormalities in children. J. Neurosurg. 57, 114-129.

Scher, A.T. (1980). Diversity of radiological features in hyperextension injury of the cervical spine. S. Af. Med. J. 58, 27-30.

Schneider, R. C., Dherry, G. and Patek, H. (1954). The syndrome of acute central cervical cord injury. With special reference to the mechanism involved in hyperextension injuries of cervical spine. J. Neurosurg. 11, 546-677. Wagner, F.C. and Chehrazi, B. (1982). Early decompression and neurological outcome in acute cervical spinal cord injuries. J. Neurosurg. 56, 699-705. 